\title{
Using the curriculum to enhance teaching and
}

AUTHOR:

Chrissie Boughey

\section{AFFILIATION:}

${ }^{1}$ Centre for Higher Education Research, Teaching and Learning (CHERTL), Rhodes University, Grahamstown, South Africa

\section{CORRESPONDENCE TO: Chrissie Boughey}

EMAIL:

C.Boughey@ru.ac.za

\section{KEYWORDS:}

higher education; curriculum reform; attrition; outcomesbased approaches

\section{HOW TO CITE:}

\section{Boughey C. Using the} curriculum to enhance teaching and learning. S Afr J Sci. 2018;114(9/10), Art \#a0288, 3 pages. https://doi. org/10.17159/sajs.2018/a0288

\section{PUBLISHED:}

11 September 2018

(C) 2018. The Author(s). Published under a Creative Commons Attribution Licence.
The publication of cohort studies tracking students' performance has given rise to concerns about the efficiency of the South African higher education system at a number of levels. These studies, which began with Scott et al.' ${ }^{1}$ pioneering work in 2007 and which have continued with the CHE's ${ }^{2}$ annual Vital Stats series, show that, regardless of the university at which they are enrolled, the subject area or the type of qualification for which they are registered, black South Africans fare less well than their white peers. At institutional levels, alarm at such observations is seen in efforts to manage success, throughput and drop-out rates through the appointment of key individuals such as deans and deputy vice chancellors responsible for teaching and learning. At a national level, concern about the performance of the system overall has led to the introduction of, first, Teaching Development Grants and, now, University Capacity Development Grants. Both of these mechanisms provide earmarked funding aimed at enhancing the quality of teaching and learning.

Although practitioners working in what is often termed the 'Academic Development Movement' have long identified the centrality of the curriculum in efforts to improve teaching and learning, ${ }^{3}$ problematic 'common sense' tends to prevail with the result that curriculum reform is neglected at the expense of ad hoc initiatives which take place outside mainstream learning.

This neglect is in spite of the fact that South Africa has been in a state of almost continuous curriculum reform for more than two decades. Curriculum reform in South Africa began with the registration of qualifications on the National Qualifications Framework (NQF) following the establishment of the South Africa Qualifications Authority in $1995 .{ }^{4}$ At the same time as the requirement to register qualifications on the NQF arose, the country was engaging with the need to participate in the global economy after years of apartheid-related isolation. As Kraak ${ }^{5}$ points out, in the early 1990s, the South African labour movement was acutely aware of the need to engage with the global economy if even higher levels of unemployment were to be avoided. As a result, the unions were happy to endorse the development of vocationally oriented programmes in higher education in order to produce the 'knowledge workers' constructed as critical to participation in the global economy by dominant discourses.

Although the former 'technikons' had always offered vocational programmes, the thinking at the time when the need to register qualifications arose led to many traditional universities moving towards offerings with a stronger workplace focus. In some cases, this resulted in wide-scale reorganisation of academic departments into schools and other structures. The emergence of three distinct types of institution as a result of the processes leading to the National Plan for Higher Education 6 in 2002 also meant that many more institutions moved towards the development of vocational programmes, particularly given the series of mergers and incorporations at that time which saw many 'traditional' universities merging with technikons to become 'comprehensive universities'.

The registration of qualifications on the NQF is dependent on the use of the 'learning outcome' as an organising principle. Learning outcomes describe what learners will be able to do upon completion of a programme of study and are typically expressed in terms of knowledge, skills and 'attitudes'. The construct of the learning outcome thus means that a common language necessary for the functioning of the framework is available to describe qualifications as they are registered.

Vocational programmes provide students with the knowledge necessary to address the learning outcomes around which they are designed. As a result of the focus on skills and the provision only of knowledge deemed necessary for a vocational area, mastery of a coherent body of disciplinary knowledge at undergraduate level has often become neglected in all but the few universities that continue to offer the general formative degree. These degrees allow students to engage with a number of different subject areas as they enter undergraduate study and to build coherent understandings of the 'knowledge structures' of the subjects they carry through to third year as 'majors'.

More than 20 years on from the time South African universities began to engage with the development of vocational programmes, the emergence of work produced in the field known as the 'sociology of knowledge', particularly that of Wheelahan ${ }^{7}$ and Maton ${ }^{8}$, challenges the thinking that has influenced curriculum reform in South Africa so heavily. These researchers argue that bodies of disciplinary knowledge are 'powerful' in that they allow knowers to move beyond the specific context for which they were trained, and for which they have mastered only the knowledge necessary to meet its demands, to other contexts. Critically, they argue that mastery of theoretical knowledge, often neglected in the focus on skills in outcomes-based approaches, allows knowers to imagine worlds that do not yet exist. Disciplinary knowledge, in the form of a cumulative 'knowledge structure', is thus seen as central to innovation and social change. Providing students with only the knowledge necessary to deal with problems in a specific context, as is the case in most vocational programmes, is seen to be particularly limiting given the pace at which the world of work is developing. Arguably, many of the jobs for which students have been trained in narrow vocational programmes will cease to exist before the end of their working lives.

The book reviewed elsewhere in this issue, Case et al.' ${ }^{9}$ Going to University, shows that the vocationally oriented programmes introduced at so many universities have another disadvantage, in that they 'lock' students into a specific programme of study. Much as a career in a particular area might have seemed attractive when students were applying to study at university, the realities of studying are often very different. As one student cited in the book notes, 'I wanted to do astrophysics when I came here, I was intent on landing on the moon, but then you get here and realise that astrophysics is actually just physics'. 
Other students in the study underpinning the book found that they were suddenly 'passionate' about a subject they encountered in the course of their studies, possibly an area they knew nothing about when they were at school. One student, for example, initially wanted to do Clinical Psychology but then, ' '...got introduced into Biological Psychology and I fell in love and it was like, "Oh my goodness, I don't want to do Clinical Psychology anymore". I'm like over it.'

The curriculum structure of a general formative degree that allows students to engage with a range of subject areas before following two of these through as 'majors' means that students can redirect themselves in ways that draw on their interests or 'passions' if their original choices fail to meet their expectations. It is not difficult to see how studying a subject that a young person feels is truly interesting would have a positive effect on academic performance.

Flexibility in the curriculum offers another critical advantage. In a tightly structured vocational programme, failing a course may mean that the student needs to repeat a year or even, if failures are repeated, to begin a completely new programme in order to attain a qualification. A flexible structure allows students to redirect themselves and find alternative routes through the curriculum without necessarily taking extra time.

In spite of the wealth of research demonstrating its centrality, the curriculum itself tends to be neglected as a means of enhancing teaching and learning. The most recent round of curriculum reforms following the publication of the Higher Education Qualifications Sub-Framework ${ }^{10}$ in 2013 have arguably led to little more than technical adjustments to curricula as institutions comply with the requirements of the framework rather than to considerations of the way curricula could impact more positively on students' experiences and, thus, to the performance of the system overall.

It is also enormously disappointing that alternatives to the 'vocational route' to the LLB qualification have been ignored in the recent CHE reaccreditation processes. Many students come into our universities thinking they want to become lawyers, or under pressure from families to become lawyers. They then often find that law is not for them, either because they fail or because the abstract study of the law in the early undergraduate years, that forms the basis for the more practice-based work that comes later, is something other than what they imagined. A route towards an LLB that consists of a 3-year general formative degree with the 2-year professional 'top up' of the law degree itself allows such students to find other pathways to a qualification and a career and, often, their passion along the way, if things go wrong. The emphasis on the 4-year LLB in the CHE accreditation processes thus has the potential to impact on the aspirations of many students to achieve a qualification if they do indeed find the law is not for them.

Curriculum reform aimed at enhancing teaching and learning could mean more than acknowledging the disadvantages of narrowly focused vocational routes. Universities have had 'Extended Programmes with an Integrated Phase' since the introduction of Foundation Programme Grants by the DHET ${ }^{11}$ in 2004. These programmes allow for the insertion of up to 120 additional 'developmental' credits in a regular accredited programme, which is then 'extended' by up to a year in order to allow for the extra tuition and study. Developmental credits do not count towards the qualification associated with the programme into which they have been inserted. Rather, the intention is that they provide the support necessary for students to engage with the 'regular' credits it requires. The DHET policy ${ }^{11}$ allocating funding for the credits allows for these developmental credits to be inserted at any point in the extended programme, although the most common practice is to locate them within the first 2 years.

Over time, a number of course types have been developed in order to accommodate these credits. These are:

- Fully foundational courses in which all the learning is aimed at filling the gaps in knowledge deemed necessary as a basis for tertiary study.

- Extended courses in which the time taken to complete a course is doubled to allow for the insertion of development credits. This might mean that a semester long course is run over an entire year with extra tuition being offered within the course.

- Augmented courses in which additional material is inserted into the regular course alongside the regular tuition time needed to complete it. This means that a semester course, offering, say, four contact periods per week, would continue to run over the length of a semester but might offer six or eight contact periods to cover the developmental credits.

It is not difficult to see how courses in regular programmes with high failure rates could be adapted to draw on these course types. Often the courses with the highest failure rates are 'gateway' courses, so called because they must be passed if a student is to proceed further. In my university, for example, a first-year 15-credit course in Cell Biology is a 'gateway' to routes through the (already flexible, general formative) curriculum in the natural sciences. The failure rates in this course were higher than those of other courses. Using funding from the Teaching Development Grant and, now, the University Capacity Development Grant, the course was developed into an 'augmented course' and a specialist in the area with a particular interest in teaching and learning was employed to teach the developmental credits. Students were enrolled in the augmented course on the basis of identified risk and attendance at the additional sessions was made a requirement. The augmented Cell Biology course has demonstrated an improvement in success rates sufficient to convince the faculty that other courses should be similarly reformed.

In the same faculty, a first-year semester-long mathematics course has been developed into an 'extended course' that now runs over the entire year for students identified as being 'at risk' because of poor results in mathematics in the National Senior Certificate. Again, funding from the development grants has been used to pay for the additional tuition costs.

An increasing number of universities are now using 'big data' in the form of tracking mechanisms to identify areas of particular difficulty. All too often, however, and as indicated earlier, remedial measures intended to address problem areas focus on the provision of additional tutorials or other forms of intervention which are not formally curriculated. Reconsidering the curriculum structure in ways outlined above offers an alternative to this sort of approach based on sound research and theory.

Clearly, the use of the curriculum structure to enhance teaching and learning in order to improve performance has implications for the availability of academic advising. Career advising at school is often poor or non-existent. As a result, students choose universities and programmes based on popular perceptions of what a career might involve (law being a case in point) or which do not sufficiently take account of their own interests, strengths and weaknesses. Case et al. ${ }^{9}$ show how participants in their study used advice provided by individuals they came across in the course of their studies in ways which often allowed them to survive and complete. Often, such advice was provided 'by chance' by an individual. This individual may have been an academic who happened to make themselves available to students through an 'open door' policy or generally friendly nature or, alternatively, someone students met who took a particular interest in them for one reason or another. Formal academic advising structures, which will allow students to make sense of their results and to plot a way forward either as they enter a university or as they progress through their studies when things are not going as expected, are an important means of enhancing performance, particularly in an institution in which attention has been paid to using the curriculum structure to improve teaching and learning.

In conclusion, therefore, curriculum restructuring offers an opportunity for those of us working in South African universities to make a real difference to our students' chances of success. The curriculum is something that students need to follow. Optional initiatives are exactly that and are opportunities for learning that are often ignored by students under pressure, an observation made by those working in academic development ${ }^{12,13}$ as long ago as the 1980s. While we have been presented with the opportunities to rework curricula, we have not always made the most of these. Perhaps now is the time to do so. 


\section{References}

1. Scott I, Yeld N, Hendry J. A case for improving teaching and learning in South African higher education. Higher Education Monitor 6. Pretoria: Council on Higher Education; 2007. Available from: http://www.che.ac.za/media and publications/higher-education-monitor/higher-education-monitor-6-caseimproving-teaching

2. Council on Higher Education. Vital stats. Pretoria: Council on Higher Education; 2016. Available from: http://www.che.ac.za/media and publications/ monitoring-and-evaluation/vitalstats-public-higher-education-2016

3. Boughey C. The significance of structure, culture and agency in supporting and developing student learning at South African universities. In: Dhunpath $R$, Vithal $R$, editors. Alternative access to higher education: Underprepared students or underprepared institutions. Cape Town: Pearson; 2012. p. 62-88.

4. Act 58 of 1995, Republic of South Africa.

5. Kraak A. Policy ambiguity and slippage: Higher education under the new state, 1994-2001. In: Kraak A, Young M, editors. Education in retrospect: Policy and implementation since 1990. Cape Town: HSRC Press; 2001.

6. Ministry of Education. The restructuring of the higher education system in South Africa. Pretoria: Ministry of Education; 2002.
7. Wheelahan L. Why knowledge matters in the curriculum. London: Routledge; 2010. https://doi.org/10.4324/9780203860236

8. Maton K. Knowledge and knowers: Towards a realist sociology of education. Abingdon: Routledge; 2013. https://doi.org/10.4324/9780203885734

9. Case JM, Marshall D, McKenna S, Mogashana D. Going to university: The influence of higher education on the lives of young South Africans. Cape Town: African Minds; 2018.

10. South African Department of Higher Education and Training. Higher education qualifications sub-framework. Government Gazette. 2014;592(38116):3-42.

11. South African Department of Education. Foundation programme grant policy. Pretoria: Department of Education; 2004.

12. Yeld N. Credit and compulsion for ASP courses: Gains and losses. In: Proceedings of the 1986 ASP Conference. Pietermaritzburg: University of Natal; 1986.

13. Foggin C. A description and assessment of the recent ASP initiatives at the University of Durban Westville with particular reference to the programme in the Faculty of Arts. In: Proceedings of the 6th Annual Conference of the South African Association for Academic Development. Johannesburg: University of the Witwatersrand; 1991. 